\title{
Power Quality Improvement of a Solar Energy Conversion System by a Coordinated Active and LCL Filtering
}

\author{
Atallah Ouai $^{1 *}$, Lakhdar Mokrani $^{1}$, Mohamed Machmoum² ${ }^{2}$ Azeddine Houari $^{2}$ \\ ${ }^{1}$ LACOSERE Laboratory, Department of Electrical Engineering, Faculty of Technology, University Amar Telidji of Laghouat, 03000 \\ Laghouat, P. O. B. 37, Algeria \\ ${ }^{2}$ IREENA Laboratory, University of Nantes, 37 Boulevard de I'Université, 44602 Saint-Nazaire, P. O. B. 406, France \\ ${ }^{*}$ Corresponding author, e-mail: a.ouai@lagh-univ.dz
}

Received: 17 September 2020, Accepted: 04 January 2021, Published online: 28 September 2021

\begin{abstract}
Power converters play an essential role in Photovoltaic (PV) system to maximize the power transfer to the electrical grid. However, the generated harmonics in the grids due to these power converters and nonlinear loads are considered one of the encountered problems to overcome. This paper presents a decoupled control of PV field real power and reactive power injected to the high voltage network via a PWM inverter by using fuzzy logic controllers. Elsewhere, a procedure based on a coordinated active and LCL filtering is proposed to mitigate the harmonic current introduced by a nonlinear load and the inverter itself in such a way to enhance the power quality injected into the grid. The results obtained in the present study show the good performance of the suggested hybrid filtering approach and demonstrate that almost all harmonics orders of the grid current are well mitigated; the current Total Harmonic Distortion (THD) meets its standard and consequently the power quality is considerably enhanced.
\end{abstract}

Keywords

photovoltaic system, electrical grid, fuzzy logic controller, non-linear load, harmonics, active filtering, LCL filter, grid current THD

\section{Introduction}

Due to ever growing integration of PV systems and nonlinear loads into the grid, power quality issues are degrading and draw more consideration $[1,2]$. Various control techniques are developed for power production and power quality enhancement using a Solar Energy Conversion System (SECS). A PV system operating in the MPPT (Maximum Power Point Tracking) mode and connected to a three phase grid incorporating with shunt Active Power Filter (APF) has been presented in $[3,4]$. In this work the photovoltaic generator is operated to produce electricity from the solar arrays and feeding to the utility network. At the same time the APF is employed to enhance the power quality of the studied PV system using $d-q$ theory. In [5], a system composed of series and shunt inverters connected back to back by a DC-link was suggested. This system is able to compensate voltage and current related problems both in inter-connected mode and islanding mode by injecting active power to the grid. In [6], the authors suggested a distortion reduction scheme, utilizing a fed forward single-phase, generation-side power conditioner with a structure that can be expanded for use in a three phase system and can work independently under imbalanced condition to compensate the plant's output current distortion, so that the total current flow to the grid is sinusoidal. In [7], to improve the power quality and the system efficiency, a double-tuned parallel resonant circuit has been proposed to attenuate the second and fourth order harmonics at the inverter DC side. In this case a modified carrier based modulation technique for the current source inverter was proposed to magnetize the DC-link inductor by shorting one of the bridge converter legs after every active switching cycle. In [8], a detailed method for selecting the LCL filter parameters and the control of the three-phase PV grid-connected inverter has been studied. Patra et al. [9], have addressed a comparative assessment for power quality that can be achieved with two types of circuits; dual stage that consists of boost based VSI (circuit type I) and a single stage using ZSI (circuit type II).

In this paper, an online fuzzy logic controller is applied to ensure a powers decoupled control of a large scale gridconnected PV system. Moreover, a hybrid control technique is suggested to enhance the power quality of the studied solar photovoltaic energy conversion system. 
This task is achieved with two kinds of filters: the LCL filter (Low Pass Filter) is used to interconnect the inverter to the utility grid in order to filter the harmonics produced by the inverter itself and active filtering to eliminate current harmonic generated by nonlinear loads. All of these two techniques may be accomplished simultaneously

Simulation results show that this coordinated filtering strategy improves the grid power quality and the current THD has met the standards as defined by IEEE Std 519-2014 [10].

\section{Structure of the studied SECS}

The SECS under analysis is the Hokuto Mega-solar project. Fig. 1 shows the configuration of this solar station, it was installed on three stages [11-13]. In this study, we only focused on the stage 02, on which we performed the Power Conditioning System (PCS) control and improving the power quality injected into the electrical grid.

The electrical and physical characteristics of this PCS are given in Table $1[13,14]$.

\section{System modeling}

The scheme of the studied SECS is presented in Fig. 2. It is formed by the PV system and the non-linear load which are connected together at the Point of Common Connection (PCC).

Many types of MPPT algorithms used to maximize the PV system output power had been developed in the literature which can be divided into two types: classical methods, such as Perturbation and Observation (P\&O), Incremental Conductance (IC), Pilot Cell (PC), and Constant-Voltage Constant-Current (CVCC); and artificial intelligent techniques, Neural Networks (NNs), Fuzzy Logic (FL), Neural-Fuzzy (NF), Genetic Algorithms (GAs), Particle Swam Optimism (PSO) and Sliding Mode (SM) [15-23]. In this work, a boost chopper has been controlled employing a pilot cell technique suggested in [24] to operate the PV system in the MPPT mode (see Fig. 3).

\section{Active filtering function}

There are various methods to identify the harmonic currents of a nonlinear load. The most classical methods are "instantaneous power theory $p-q$ " or $" d-q$ or synchronous detection method". Practically, a Selective Pass Band Filter (SPBF) or Low Pass Filter (LPF) can been used to extract the harmonic currents components [25]. Frequency domain compensation, which is based on Fourier analysis, is not very used because it requires more real time processing power [26]. In this case, the instantaneous power

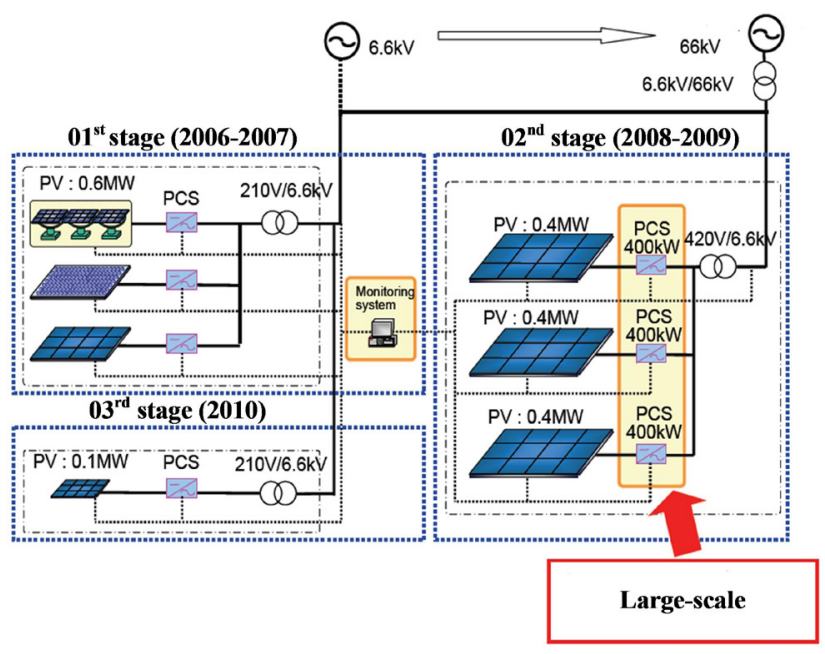

Fig. 1 System configuration [13]

Table 1 Specification of PCS [14]

\begin{tabular}{ll}
\hline Capacity & $420 \mathrm{kVA} / 400 \mathrm{~kW}$ \\
AC voltage & $420 \mathrm{~V} \pm 10 \%$ \\
DC voltage & $600 \mathrm{~V}$ \\
Input DC voltage & $230-600 \mathrm{~V}$ \\
Switching frequency & $4-6 \mathrm{kHz}$ \\
Conversion efficiency & $>95 \%(30 \%-100 \%)$ \\
Control functions & MPPT \\
& Reducing harmonics \\
\hline
\end{tabular}

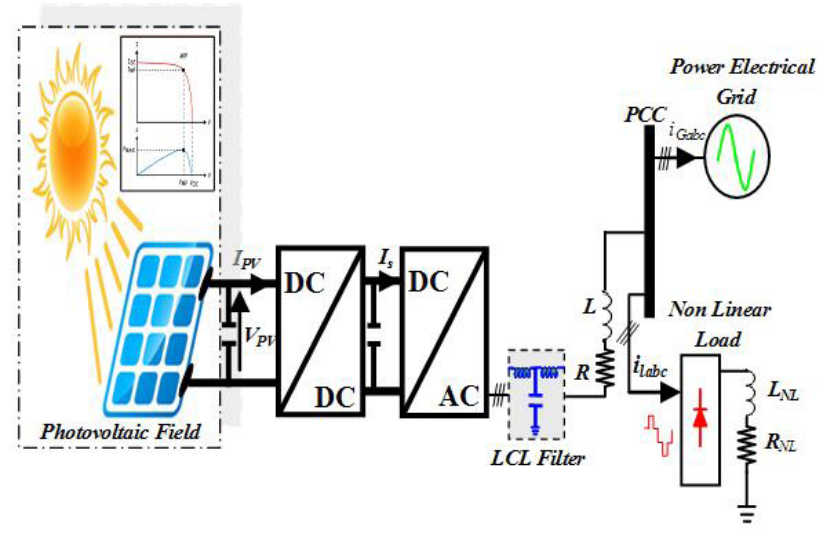

Fig. 2 Proposed SECS

theory is used for being compensated, by the grid side converter as shown in Fig. 3. The resulting $d-q$ reference harmonic currents $\left(i_{l d h}, i_{l q h}\right)$ must be subtracted from the currents $\left(i_{\text {dref }}, i_{\text {qref }}\right)$.

\section{LCL filter}

The use of the LCL filter gives the improved harmonic suppression ability at the lower frequency range and it is useful in the high power applications. It's a $3^{\text {rd }}$ order filter whose one side is connected to the inverter and the other end is connected to the grid $[27,28]$. The resonance effect 


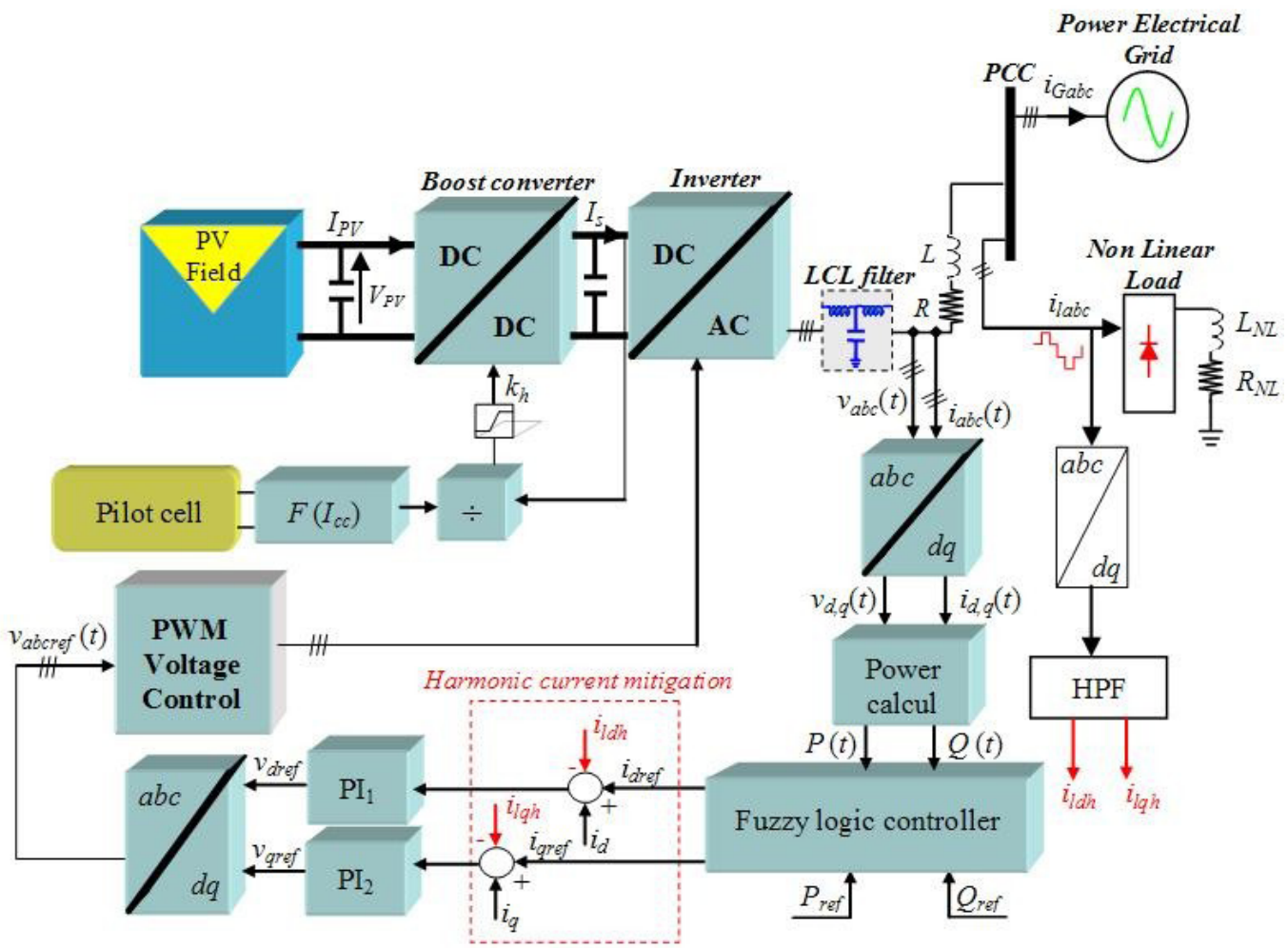

Fig. 3 Grid-connected PV system control diagram with harmonics filtering using actif and LCL filter

can cause voltage instability or current around the resonant frequency. In order to solve this problem, damping resistor can be added to the LCL circuit [29].

\subsection{Model of the LCL filter}

The equivalent single phase LCL-filter configuration is shown in Fig. 4 [29], where $L_{1}$ is the inverter side inductor, $L_{2}$ is the grid-side inductor, $C_{f}$ is a capacitor with a series $R_{f}$ damping resistor. The voltage and current at the grid side are represented as $v_{G}$ and $i_{G a}$, respectively [30, 31].

\subsection{LCL Filter design criteria}

The base impedance of the system must be given for choosing the LCL filter parameters in order to avoid resonance, voltage drop and reactive power problems [32].

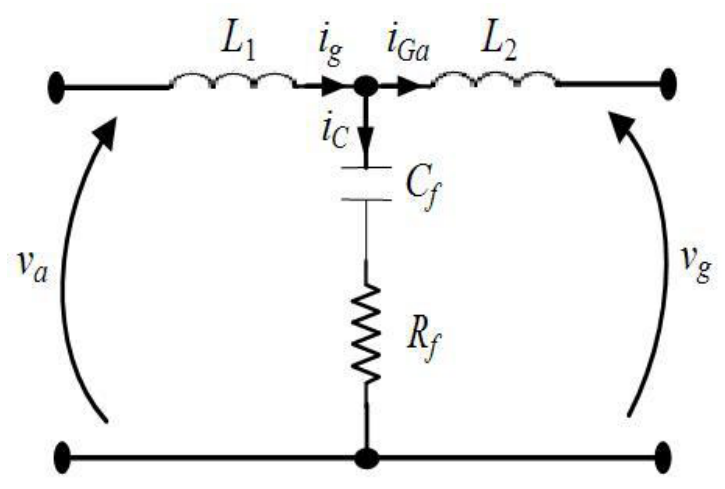

Fig. 4 Proposed LCL filter equivalent circuit [29]
The base values of each component of the LCL filter are defined as [33, 34]:

$Z_{b}=\frac{E_{n}^{2}}{P_{n}}$,

$C_{b}=\frac{1}{\omega_{n} Z_{b}}$

$L_{b}=\frac{Z_{b}}{\omega_{n}}$

where $E_{n}$ is the line to line RMS voltage, $\omega_{n}$ is the grid frequency and $P_{n}$ is the active power absorbed by the converter in rated conditions.

The criteria of LCL filter design are described as followings [28-35]:

1. The total inductance value of both inverter side inductor and grid side inductor should be lower than $10 \%$ of base inductance value to limit the voltage drop at inductors during the operation:

$$
L_{T} \leq 0.1 L_{b}
$$

2. The filter capacitance value should be less than $15 \%$ of the base capacitance in order to limit the reactive power at the rated power:

$C_{f} \leq 0.15 C_{b}$. 
3. The resonance frequency should be in the range between ten times of line frequency and one half of switching frequency to avoid the resonance problem:

$$
10 f_{n} \leq f_{\text {res }} \leq 0.5 f_{\mathrm{s}} \text {. }
$$

Using LCL filter, seen in Fig. 4, the resonance frequency depends only on filter parameters [35]:

$f_{\text {res }}=\frac{1}{2 \pi} \sqrt{\frac{L_{1}+L_{2}}{L_{1} L_{2} C_{f}}}$.

The damping resistor is expressed as follows [29]:

$$
R_{f}=\frac{1}{3 \omega_{\text {res }} C_{f}} .
$$

Moreover, inverter-side inductor can be calculated according to Eq. (9) [34]:

$$
L_{1}=\frac{V_{g}}{2 \sqrt{6} f_{s} \Delta i},
$$

where $\Delta i$ is the current ripple peak which can be chosen as $0.15 \sim 0.25$ of the rated current. In this paper, the current ripple is selected as $20 \%$ of the rated current.

$\Delta i=20 \% I_{\text {rated }}$

In this case a ratio $(r=0.46)$ between the inductance at the inverter side and the one at the grid side has been chosen [35].

One can write:

$$
L_{2}=r L_{1} \text {. }
$$

Thus, the calculated LCL parameters set used condition used is depicted in Table 2, where the values of $L_{1}, L_{2}$ and $C_{f}$ are obtained from the Eqs. (5) to (11).

\section{Simulation results and discussion}

The whole photovoltaic energy conversion system and the proposed filtering strategy have been simulated under standard conditions $\left(T=25^{\circ} \mathrm{C}\right.$ and, $\left.E=1000 \mathrm{~W} / \mathrm{m}^{2}\right)$. The PV system is connected to the grid. A non-linear load is connected also at the PCC (see Fig. 3). Here after simulations are performed under different load conditions as well as various filtering techniques (Active filtering and/ or LCL filter are presented and discussed).

\subsection{Grid-connected PV system without filtering}

To ensure the decoupled power control of a three-phase voltage PWM inverter, the powers are controlled by the
Table 2 Condition values for LCL filter design

\begin{tabular}{ll}
\hline Parameter & Value \\
\hline Grid voltage, $V_{g}$ (RMS) & $420 / \sqrt{ } 3 \mathrm{~V}$ \\
Inverter Power, $P_{n}$ & $400 \mathrm{~kW}$ \\
DC Link voltage, $V_{d c}$ & $900 \mathrm{~V}$ \\
Grid frequency, $f_{n}$ & $60 \mathrm{~Hz}$ \\
Swiching frequency, $f_{s}$ & $4 \mathrm{kHz}$ \\
Inverter side inductor, $L_{1}$ & $80 \mu \mathrm{H}$ \\
Grid-side inductor, $L_{2}$ & $40 \mu \mathrm{H}$ \\
LCL Filter capacitor, $C_{f}$ & $900 \mu \mathrm{F}$ \\
LCL Filter damping resistor, $R_{f}$ & $60 \mathrm{~m} \Omega$ \\
\hline
\end{tabular}

line current components $i_{d}$ and $i_{q}$. In this study, the power injected to the grid is a purely active power and the grid power factor is maintained at unity setting the reactive power command to zero $\left(P_{r e f}=120 \mathrm{~kW}\right.$ and $\left.Q_{\text {ref }}=0 \mathrm{kVAr}\right)$ as shown in Fig. 5 (a). It is noted from this figure that $P$ and $Q$ track accurately their references $P_{r e f}$ and $Q_{r e f}$ respectively in this case of active power generation; therefore the decoupling control of the real power and reactive power is successfully performed. Moreover, Fig. 5 (b) shows the grid current waveform without harmonic filters and its spectrum is shown in Fig. 5 (c) with a THD value of $5.40 \%$ at $4 \mathrm{kHz}$ switching frequency (see Table 1) which is lies above $5 \%$ of the IEEE standard 519 [10] (the THD of the three phase currents lie around $5 \%$ ).

\subsection{Grid-connected PV system with an LCL filter}

In this case, an LCL filter is used at the output of the inverter in order to filter the harmonics produced by this converter. The filtered grid current waveform is shown in Fig. 6 (a). It is practically sinusoidal thanks to the good adjusting of the damping factor of the LCL filter. In fact, the harmonic spectrum of the current injected to the grid as shown in Fig. 6 (b), has a little THD of $1.41 \%$.

In addition, Table 3 summarizes the simulation results of the grid current THD with and without LCL filtering, for some illumination intensity levels. It shows the effectiveness of this filter in terms of the grid current depollution especially in the case of low irradiation levels.

\subsection{Grid-connected PV system in presence of a non- linear load without any filtering}

Nonlinear loads connected to the grid produce harmonic currents, which causes deterioration in power quality.

The modern SECS are controlled not only to maximize the energy captured from the solar, but also to improve the quality of the power injected into the electrical grid. 


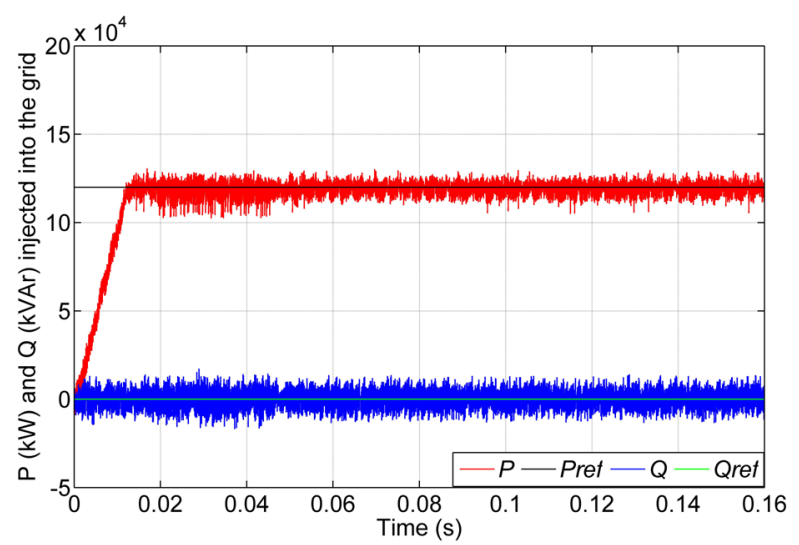

(a)

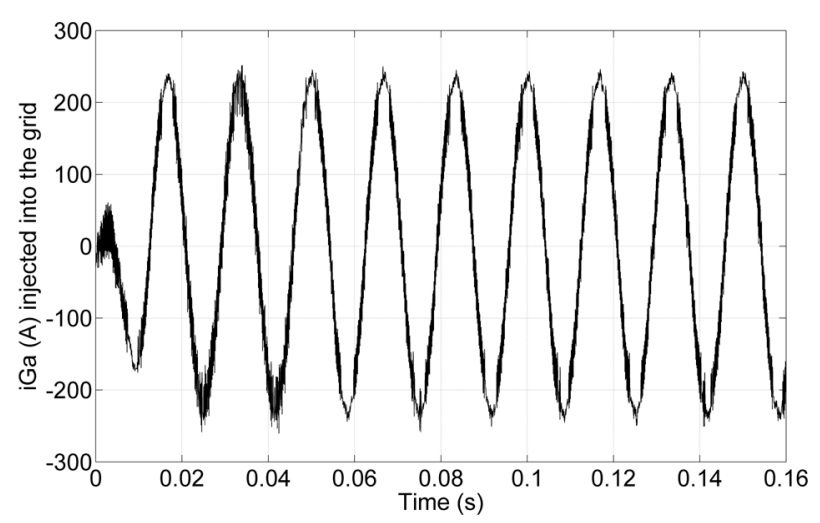

(b)

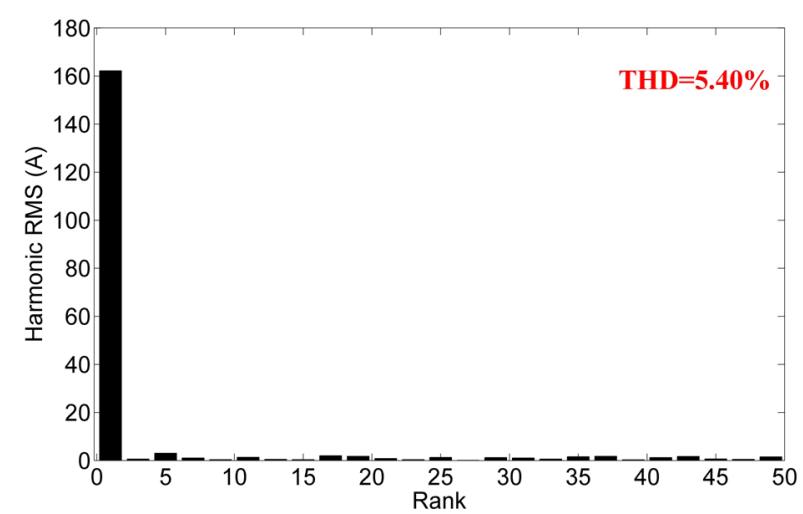

(c)

Fig. 5 Simulation results of a grid-connected PV system without any filtering (a) Active and reactive powers in (kW) and (kVAr), (b) Grid current $i_{G a}(\mathrm{~A})$, (c) Grid current spectrum

The considered non-linear load of $80 \mathrm{~kW}$ is connected at the bus bar. It is supplied by the PV system and absorbs current which is shown in Fig. 7 (a).

Moreover, Fig. 7 (b) shows the harmonic component of the non-linear load current which can effectively be suppressed by using active filtering. In this case, the PV system provides $120 \mathrm{~kW}$ to the grid $\left(P_{r e f}=120 \mathrm{~kW}\right.$ and $\left.Q_{\text {ref }}=0 \mathrm{kVAr}\right)$.

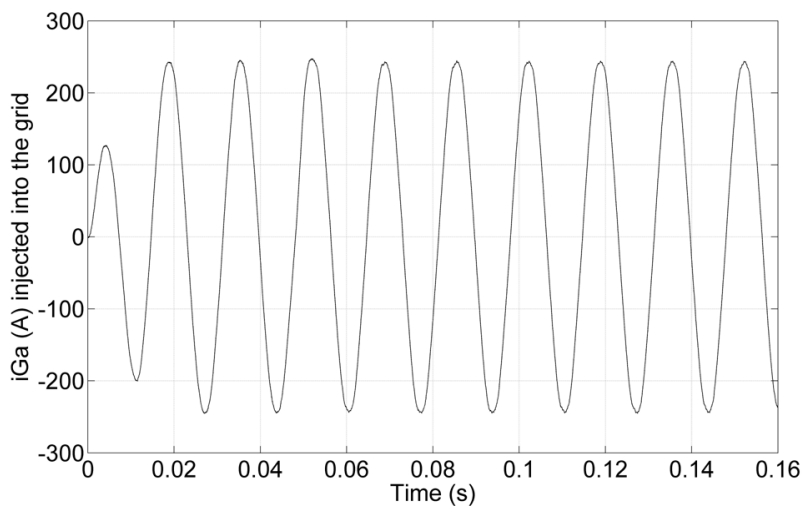

(a)

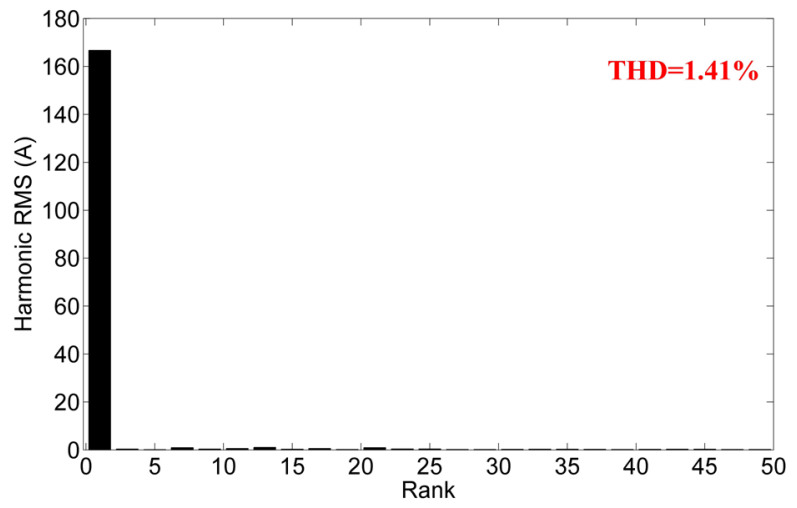

(b)

Fig. 6 Simulation results of the PV system equipped with an LCL filter (a) Grid current $i_{G a}(\mathrm{~A})$, (b) Grid current spectrum

Table 3 Grid current THD during variable irradiation

\begin{tabular}{cccc}
\hline$E\left(\mathrm{~W} / \mathrm{m}^{2}\right)$ & $P(\mathrm{~kW})$ & \multicolumn{2}{c}{ THD $(\%)$} \\
& & Without filtering & With LCL Filter \\
\hline 1000 & 100 & 5.64 & 1.65 \\
900 & 90 & 5.52 & 1.68 \\
800 & 85 & 6.34 & 1.73 \\
700 & 80 & 6.30 & 1.88 \\
600 & 75 & 7.20 & 1.59 \\
500 & 70 & 7.42 & 1.79 \\
400 & 60 & 10.15 & 1.93 \\
\hline
\end{tabular}

In this case, the DC capacitor voltage is maintained constant practically by the control of the inverter as shown in Fig. 8 (a).

Also, Fig. 8 (b) illustrates the grid current waveform which becomes more distorted when the nonlinear load is integrated into the grid.

The THD of the grid current without filtering (Active filtering and/or LCL filter) is $10.49 \%$, as shown in Fig. 8 (c). It can be noted that this THD is high. 


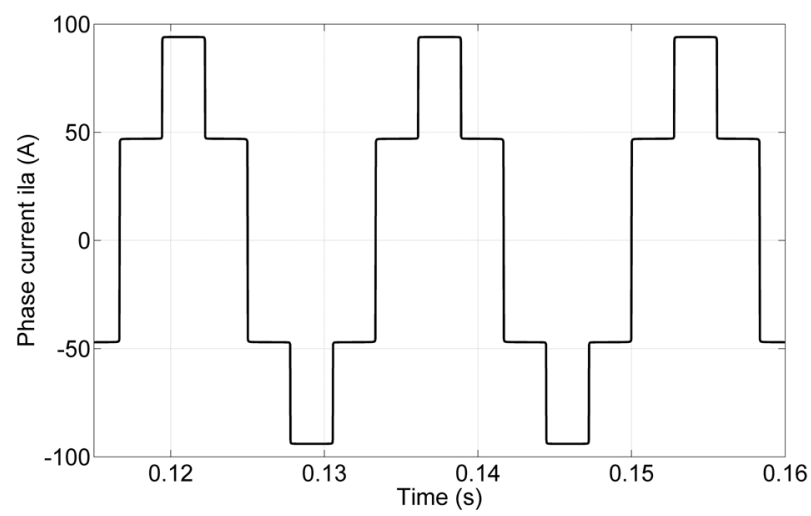

(a)

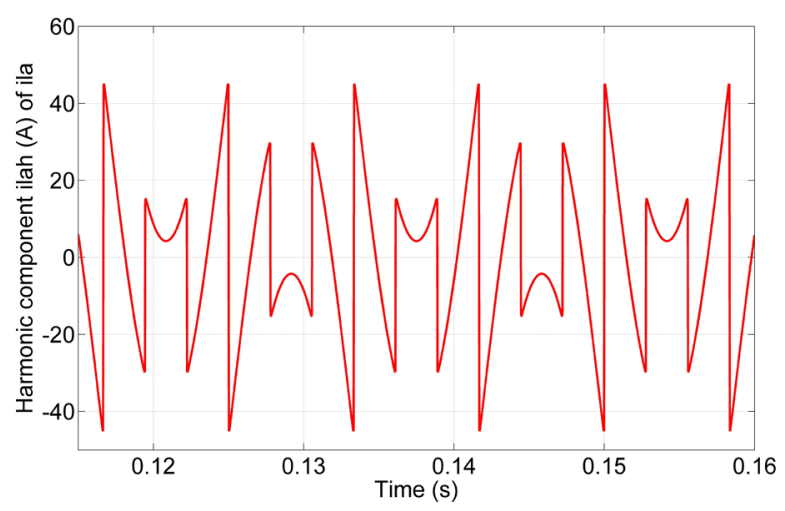

(b)

Fig. 7 Non-linear load current and its harmonic component (a) Phase current $i_{l a}$ (A), (b) Harmonic component part current $i_{l a h}(\mathrm{~A})$ of $i_{l a}$

\subsection{Grid-connected PV system in presence of non-linear load with active filtering}

The performance of the SECS, in terms of active filtering, is now studied under the previous conditions. The main goal is to mitigate the harmonic currents of the non linear load which has a harmonic distortion ratio of $10.49 \%$. Fig. 9 shows the simulation results.

Fig. 9 (a) illustrates the grid current waveform in presence of active filtering. It shows clearly the performance of the filtering strategy in terms of power quality improvement.

From Fig. 9 (b), one can see small oscillations of the DC-bus voltage.

Moreover, in this case of the grid current spectrum shown in Fig. 9 (c), after active filtering, prove the enhancement of the grid current THD which is reduced from about $10.49 \%$ to $5.11 \%$ but remains higher than IEEE standard 519 [10]. In this way, the $5^{\text {th }}$ and the $7^{\text {th }}$ harmonics decrease from $12.41 \mathrm{~A}$ to $3.43 \mathrm{~A}$ and from $8.35 \mathrm{~A}$ to 1.66 A respectively.

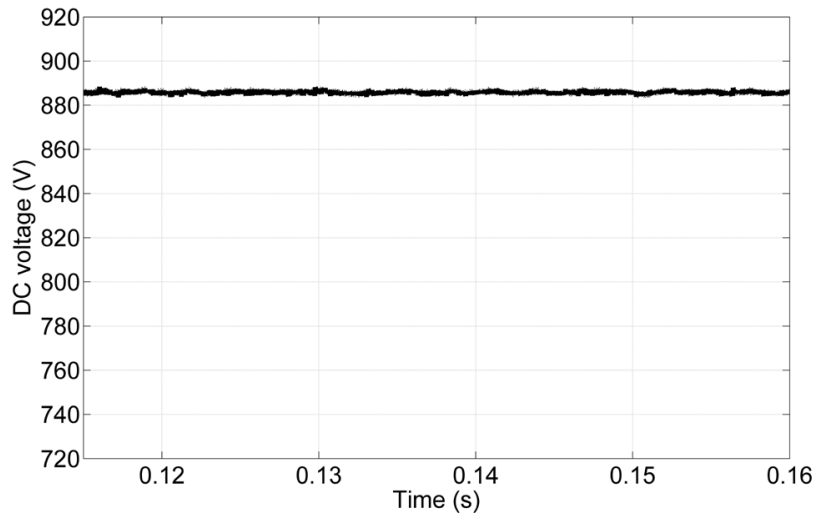

(a)

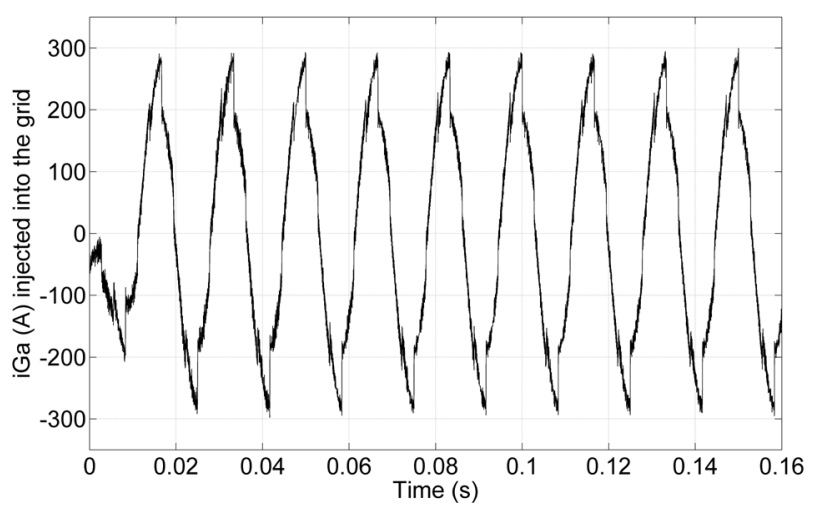

(b)

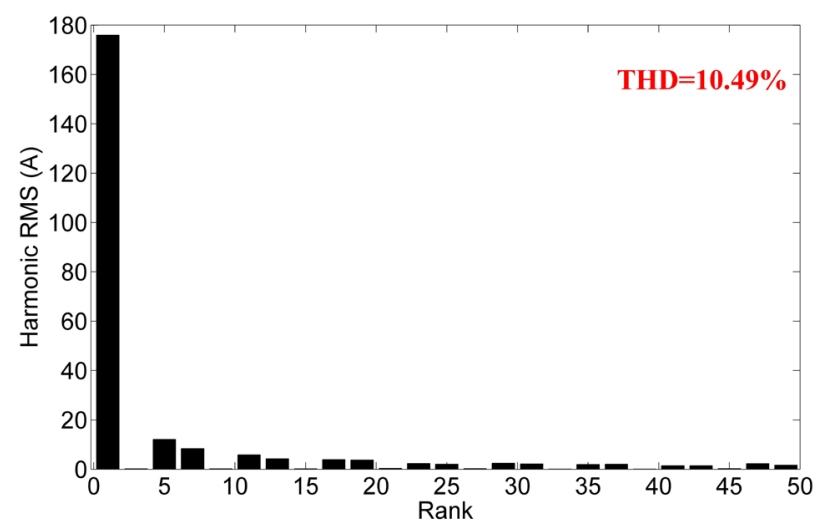

(c)

Fig. 8 Simulation results of the PV system in presence of the non-linear load without any filtering (a) DC voltage (V), (b) Grid current $i_{G a}$ (A),

(c) Grid current spectrum

6.5 Grid-connected PV system equipped by an LCL filter in presence of a non-linear load

Let us evaluate now the operation of the PV system equipped by an LCL filter, in presence of a nonlinear load. 


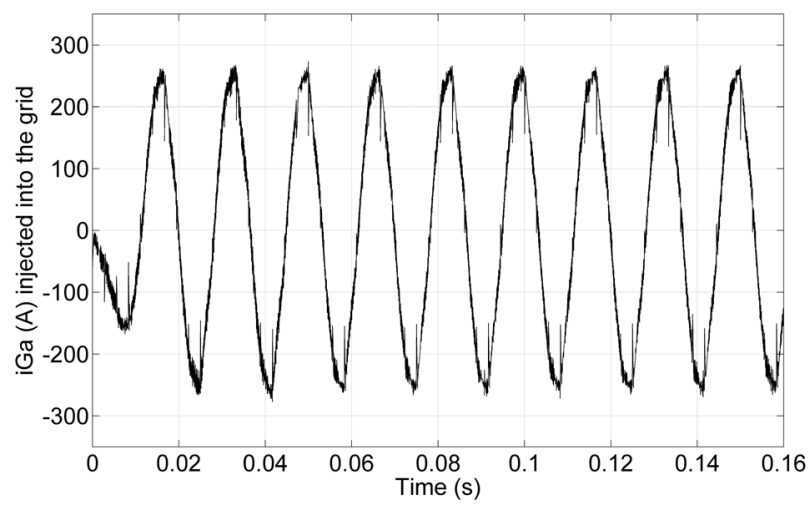

(a)

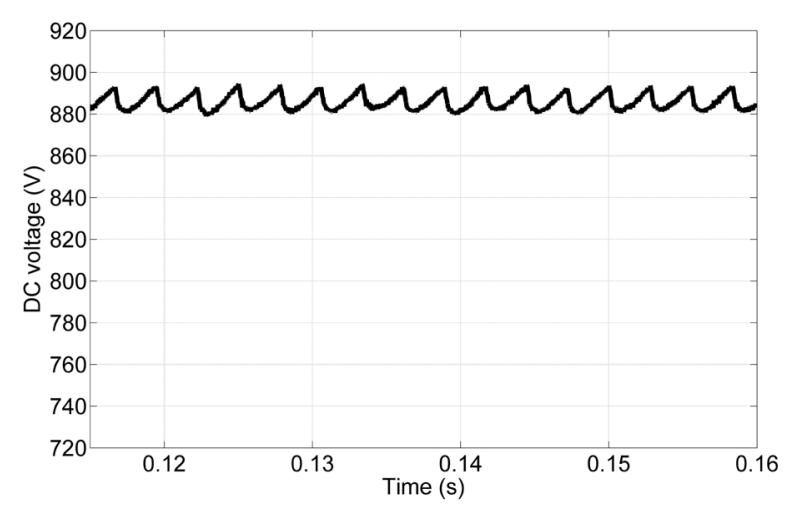

(b)

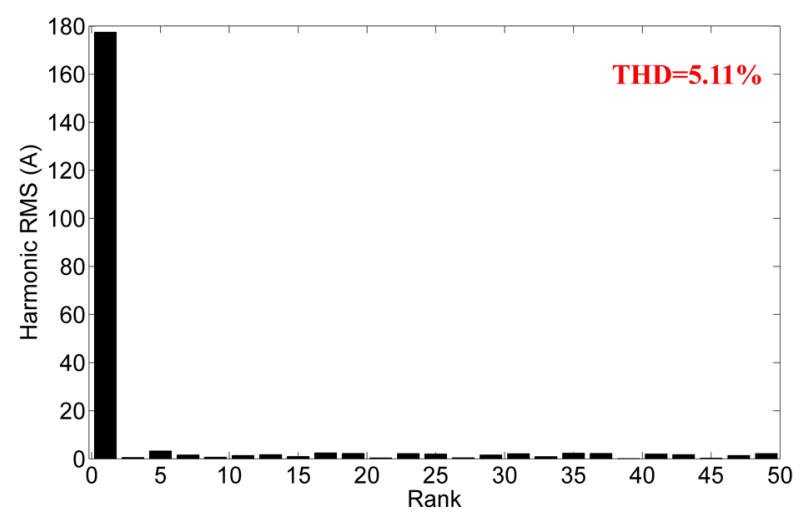

(c)

Fig. 9 Simulation results of the PV system with active filtering only (a) Grid current $i_{G a}$ (A), (b) DC voltage (V), (c) Grid current spectrum

Fig. 10 illustrates the simulations performed in this case. According to Fig. 10 (a), the nonlinear load harmonic currents are not totally filtered and a bad current waveform output is observed. The spectrum undoubtedly shows a poorer performance than the IEEE standard [10] with its THD of $9.33 \%$ in exceeds that the normal $5 \%$ limit (Fig. 10 (b)).

\subsection{Grid-connected PV system equipped with active} filtering and LCL filter in presence of a non-linear load In this case, in order to improve even more the power quality, a hybrid filtering procedure is used to well reduce all

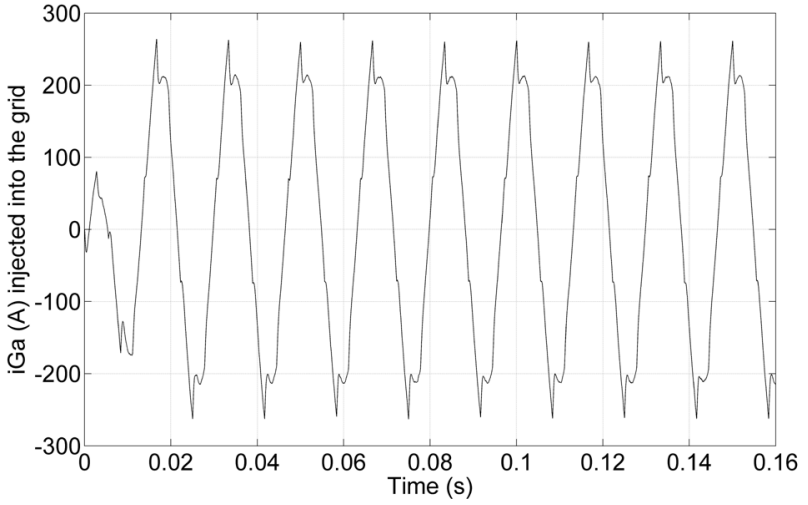

(a)

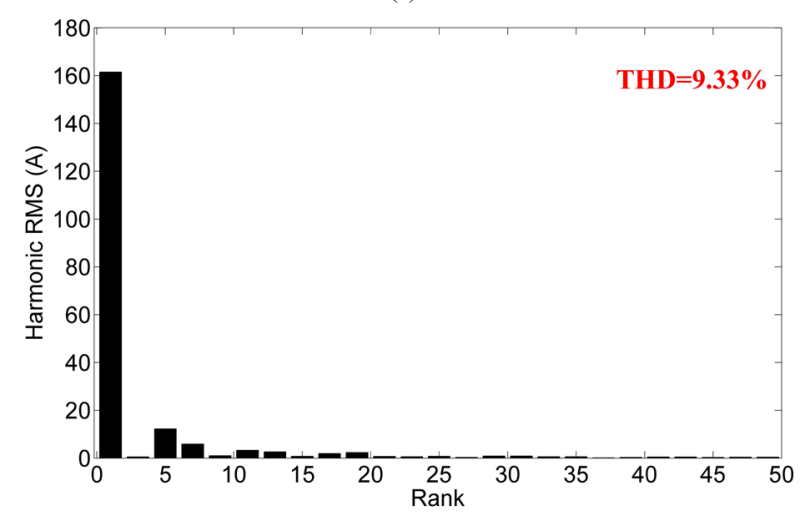

(b)

Fig. 10 Simulation results of the PV system equipped with LCL filter in presence of a non-linear load (a) Grid current $i_{G a}$ (A), (b) Grid current spectrum

harmonic rank generated from the PWM control of the inverter and the non linear load, so that the grid current has become a sinusoidal wave of $60 \mathrm{~Hz}$. The waveforms shown in Fig. 11: grid current $\left(i_{G a}\right)$ and its spectrum show clearly the performance of the proposed strategy in terms of power quality improvement.

After filtering (by coordination of the two actions of active filtering and LCL filter) as can be remarked from Fig. 11 (a), the grid current signal is closer to the sinusoidal form. Elsewhere, from the grid current spectrum, shown by Fig. 11 (b), it has been deduced that its THD is reduced from about $10.49 \%$ to $2.33 \%$. Note that, in this case, the most harmonics of the grid current are properly mitigated and the THD meets the IEEE Std 519-2014 [10].

\section{Conclusion}

In this paper, a decoupled fuzzy control of the PV system real and reactive power injected to the grid is successfully applied. The power quality of the studied SECS is enhanced via filtering operation (Active filtering and/or LCL filter). The parameter-design method of the LCL filter is performed for a three-phase grid connected inverter system used in 


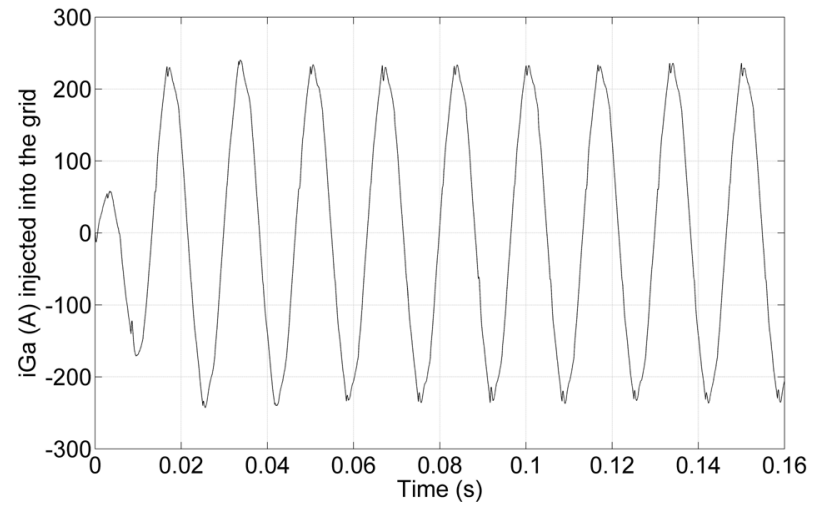

(a)

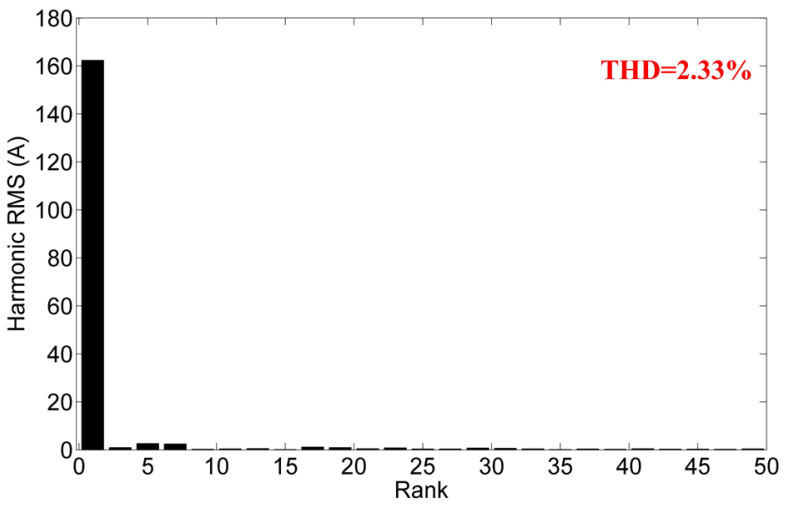

(b)

Fig. 11 Simulation results of PV system equipped by active filtering and LCL filter (a) Grid current $i_{G a}$ (A), (b) Grid current spectrum

a large scale grid connected PV system. The implementation of this filter reduces the harmonic content of PV system caused by the inverter. In addition, this paper has also shown the improved power quality by using an active filtering approach for harmonic suppression of non-linear load to

\section{References}

[1] Rezvani, A., Gandomkar, M., Izadbakhsh, M., Vafaei, S. "Improvement of Grid-Connected Photovoltaic System Using Artificial Neural Network and Genetic Algorithm Under Different Condition", International Journal of Soft Computing, Mathematics and Control, 3(4), pp. 15-32, 2014.

https://doi.org/10.14810/ijscmc.2014.3402

[2] Li, J., Zhuo, F., Wang, X., Wang, L., Ni, S. "A grid-connected PV system with power quality improvement based on boost + duallevel four-leg inverter", In: 2009 IEEE 6th International Power Electronics and Motion Control Conference, Wuhan, China, 2009, pp. 436-440.

https://doi.org/10.1109/ipemc.2009.5157427

[3] Ibrahim, Z., Abu hasim, A. S., Talib, M. H. N., Mat Lazi, J., Mat Isa, S. N., Mustafa, R. "Performance investigations of photovoltaic grid connection for shunt active power filter with different PWM generation", Journal of Theoretical and Applied Information Technology, 57(2), pp. 305-312, 2013.

[4] Sreerami Reddy, N., Hameed, S. K. "Fuzzy Based Current Harmonic Suppression and Reactive Power Compensation in a Grid Connected PV System Using Shunt Active Filter", International Journal of Science and Research, 4(5), pp. 2102-2107, 2015.

[5] Ramalingeswara Rao, K., Srikanth, K. S. "Improvement of Power Quality using Fuzzy Logic Controller In Grid Connected Photovoltaic Cell Using UPQC", International Journal of Power Electronics and Drive System (IJPEDS), 5(1), pp. 101-111, 2014. https://doi.org/10.11591/ijpeds.v5i1.6184

[6] Hamid, M. I., Jusoh, A. "Reduction of waveform distortion in grid-injection current from single-phase utility interactive PV-inverter", Energy Conversion and Management, 85, pp. 212-226, 2014. https://doi.org/10.1016/j.enconman.2014.05.031 meet the standards and limits required for interconnection.

Simulation results have shown that a coordination between active filtering and LCL filter, the grid current THD has gone down to $2.33 \%$ as compared to the system without any filter at $10.49 \%$.

[7] Naveena, M., Kuthsiyatjahan, S. "Power quality improvement in grid-connected PV system based on double tuned resonant filter", International Journal of Science, Engineering and Technology Research, 12(4), pp. 4369-4374, 2015.

[8] Yin, W., Ma, Y. "Research on three-phase PV grid connected inverter based on LCL filter", In: 2013 IEEE 8th Conference on Industrial Electronics and Applications (ICIEA), Melbourne, VIC, Australia, 2013, pp. 1279-1283. https://doi.org/10.1109/ICIEA.2013.6566564

[9] Patra, S., Kishor, N., Mohanty, S. R., Ray, P. K. "Power quality assessment in 3- $\Phi$ grid connected PV system with single and dual stage circuits", International Journal of Electrical Power and Energy Systems, 75, pp. 275-288, 2016. https://doi.org/10.1016/j.ijepes.2015.09.014

[10] IEEE "IEEE Std 519-2014 - IEEE Recommended Practice and Requirements for Harmonic Control in Electric Power Systems", (Revision of IEEE Std 519-1992), IEEE, New York, USA, 2014. https://doi.org/10.1109/IEEESTD.2014.6826459

[11] Konishi, H., Tanaka, R., Shiraki, T. "The Hokuto mega-solar project", Solar Energy Materials and Solar Cells, 93(6-7), pp. 1091-1094, 2009. https://doi.org/10.1016/j.solmat.2008.12.020

[12] Konishi, H., Iwato, T., Kudou, M. "Verification test results of 2nd stage in hokuto mega-solar system", In: 2011 37th IEEE Photovoltaic Specialists Conference, Seattle, WA, USA, 2011, pp. 2375-2379. https://doi.org/10.1109/PVSC.2011.6186428

[13] Konishi, H., Kudou, M., Miyata, H., Ueda, Y. "Five-year's verification test results in Hokuto mega-solar system", In: 2012 38th IEEE Photovoltaic Specialists Conference, Austin, TX, USA, 2012, pp. 543-548. https://doi.org/10.1109/PVSC.2012.6317673 
[14] Konishi, H. "Study of MPPT Control Method for Large-scale Power Conditioning System in Hokuto Mega-solar System", Journal of International Council on Electrical Engineering, 4(2), pp. 173-178, 2014.

https://doi.org/10.5370/JICEE.2014.4.2.173

[15] Franco, F. D., Vu, T. V., Gonsulin, D., Vahedi, H., Edrington, C. S. "Enhanced performance of PV power control using model predictive control", Solar Energy, 158, pp. 679-686, 2017. https://doi.org/10.1016/j.solener.2017.10.005

[16] Al-Majidi, S. D., Abbod, M. F., Al-Raweshidy, H. S. "A novel maximum power point tracking technique based on fuzzy logic for photovoltaic systems", International Journal of Hydrogen Energy, 43(31), pp. 14158-14171, 2018.

https://doi.org/10.1016/j.ijhydene.2018.06.002

[17] Elgendy, M. A., Zahawi, B., Atkinson, D. J. "Assessment of the Incremental Conductance Maximum Power Point Tracking Algorithm", IEEE Transactions on Sustainable Energy, 4(1), pp. 108-117, 2013. https://doi.org/10.1109/TSTE.2012.2202698

[18] Muthuramalingam, M., Manoharan, P. S. "Comparative analysis of distributed MPPT controllers for partially shaded stand alone photovoltaic systems", Energy Conversion and Management, 86, pp. 286-299, 2014.

https://doi.org/10.1016/j.enconman.2014.05.044

[19] Seyedmahmoudian, M., Horan, B., Soon, T. K., Rahmani, R., Muang Than Oo, A., Mekhilef, S., Stojcevski, A. "State of the art artificial intelligence-based MPPT techniques for mitigating partial shading effects on PV systems -A review", Renewable and Sustainable Energy Reviews, 64, pp. 435-455, 2016. https://doi.org/10.1016/j.rser.2016.06.053

[20] Bechouat, M., Soufi, Y., Sedraoui, M., Kahla, S. "Energy storage based on maximum power point tracking in photovoltaic systems: A comparison between GAs and PSO approaches", International Journal of Hydrogen Energy, 40(39), pp. 13737-13748, 2015. https://doi.org/10.1016/j.ijhydene.2015.05.008

[21] Koad, R. B. A., Zobaa, A. F., El-Shahat, A. "A Novel MPPT Algorithm Based on Particle Swarm Optimization for Photovoltaic Systems", IEEE Transactions on Sustainable Energy, 8(2), pp. 468-476, 2017. https://doi.org/10.1109/TSTE.2016.2606421

[22] Duman, S., Yorukeren, N., Altas, I. H. "A novel MPPT algorithm based on optimized artificial neural network by using FPSOGSA for standalone photovoltaic energy systems", Neural Computing and Applications, 29(1), pp. 257-278, 2018.

https://doi.org/10.1007/s00521-016-2447-9

[23] Benlarbi, K., Mokrani, L., Nait-Said, M. S. "A fuzzy global efficiency optimization of a photovoltaic water pumping system", Solar Energy, 77(2), pp. 203-216, 2004. https://doi.org/10.1016/j.solener.2004.03.025

[24] Ouai, A., Mokrani, L., Machmoum, M., Houari, A. "Control and energy management of a large scale grid-connected PV system for power quality improvement", Solar Energy, 171, pp. 893-906, 2018. https://doi.org/10.1016/j.solener.2018.06.106
[25] Boutoubat, M., Mokrani, L., Machmoum, M. "Control of a wind energy conversion system equipped by a DFIG for active power generation and power quality improvement", Renewable Energy, 50, pp. 378-386, 2013.

https://doi.org/10.1016/j.renene.2012.06.058

[26] Prabhakar, C., Bhattar, C. L. "Performance and analysis of PV system at utility level with harmonics mitigation using passive LCL filter", In: 2015 IEEE 9th International Conference on Intelligent Systems and Control (ISCO), Coimbatore, India, 2015, pp. 1-6. https://doi.org/10.1109/ISCO.2015.7282287

[27] Lakshmanan, S. A., Rajpurohit, B. S., Jain, A. "Design and analysis of current controllers with active damped LCL filter for three-phase grid connected solar PV system", In: 2015 IEEE Innovative Smart Grid Technologies - Asia (ISGT ASIA), Bangkok, Thailand, 2015, pp. $1-5$.

https://doi.org/10.1109/ISGT-Asia.2015.7387068

[28] Hojabri, Mo., Hojabri, Me., Toudeshki, A. "Passive Damping Filter Design and Application for Three-Phase PV Grid-Connected Inverter", International Journal of Electrical, Electronics and Data Communication, 3(6), pp. 50-56, 2015.

[29] Reznik, A., Simões, M. G., Al-Durra, A., Muyeen, S. M. "LCL Filter Design and Performance Analysis for Grid-Interconnected Systems", IEEE Transactions on Industry Applications, 50(2), pp. 1225-1231, 2014. https://doi.org/10.1109/TIA.2013.2274612

[30] Hojabri, Mo., Hojabri, Me. "Design, Application and Comparison of Passive Filters for Three-Phase Grid-Connected Renewable Energy Systems", ARPN Journal of Engineering and Applied Sciences, 10(22), pp. 10691-10697, 2015.

[31] Lim, S., Choi, J. "LCL filter Design for Grid Connected NPC Type Three-Level Inverter", International Journal of Renewable Energy Research, 5(1), pp. 45-53, 2015.

[32] Tang, Y., Loh, P. C., Wang, P., Choo, F. H., Gao, F., Blaabjerg, F. "Generalized Design of High Performance Shunt Active Power Filter with Output LCL Filter", IEEE Transactions on Industrial Electronics, 59(3), pp. 1443-1452, 2012. https://doi.org/10.1109/TIE.2011.2167117

[33] Tahami, H., Hosseini, S. M., Adabi, J. "A Flexible Control Method for Integration of Distributed Generation Resources to the Power Grid in Presence of Nonlinear Load and Unbalanced Voltage", International Journal of Mechatronics, Electrical and Computer Technology, 4(12), pp. 1297-1327, 2014.

[34] Tripathi, R. N., Alka, S., Hanamoto, T. "Design and control ofLCL filter interfaced grid connected solar photovoltaic (SPV) system using power balance theory", International Journal of Electrical Power \& Energy Systems, 69, pp. 264-272, 2015. https://doi.org/10.1016/j.ijepes.2015.01.018

[35] Xu, R., Xia, L., Zhang, J., Ding, J. "Design and Research on the LCL Filter in Three-Phase PV Grid-Connected Inverters", International Journal of Computer and Electrical Engineering, 5(3), pp. 322-325, 2013.

https://doi.org/10.7763/IJCEE.2013.V5.723 